\title{
Removal of textile azo dyes with mixed biomass of Aspergillus niger and orange peel (Citrus sinensis L. Osbeck)
}

Remoção de corantes azo têxteis por meio da biomassa mista Aspergillus niger e casca de laranja (Citrus sinensis L. Osbeck)

\author{
K. C. de Souza ${ }^{1 *}$; T. E. P. da Silva ${ }^{2}$; L. P. S. Oliveira ${ }^{2}$; A. N. R. Leal ${ }^{3}$; I. J. da Cruz \\ Filho $^{4}$; M. J. F. da Silva ${ }^{1 *}$ \\ ${ }^{1}$ Department of Chemistry, Rural Federal University of Pernambuco, 52171-900, Recife-PE, Braszl \\ ${ }^{2}$ Department of Chemistry Engineering, Federal University of Pernambuco, 50740-540, Recife-PE, Brazil \\ ${ }^{3}$ Department of Materials Science, Federal University of Pernambuco, 50740-560, Recife-PE, Brazil \\ ${ }^{4}$ Department of Antibiotics, Federal University of Pernambuco, 50740-540, Recife-PE, Brazil \\ *karina.carvalhosouza@ufpe.br \\ (Recebido em 14 de novembro de 2020; aceito em 03 de junho de 2021)
}

\begin{abstract}
This study evaluates the removal of textile dyes using mixed adsorbents prepared by the growth of Aspergillus niger in orange peels. The highest azo dye removal efficiency was obtained at $\mathrm{pH} 2$, solid: liquid ratio (1: 4 $\mathrm{g} \cdot \mathrm{mL}^{-1}$ ) and time of equilibrium of 250 minutes for each dye. The concentrations of Remazol Black B (RB) and Remazol Red (RR) in both synthetic textile effluents were between $25 \mathrm{mg} \cdot \mathrm{L}^{-1}$ and $100 \mathrm{mg} \cdot \mathrm{L}^{-1}$. The mixed adsorbent was characterized by X-ray diffraction (XRD), spectroscopy infrared region (FTIR) and scanning electron microscopy (SEM). The results indicated that there was a 100\% removal of RB and $94.85 \%$ of RR at the concentration of $25 \mathrm{mg} \cdot \mathrm{L}^{-1}$. At the concentration of $100 \mathrm{mg} \cdot \mathrm{L}^{-1}$, the percentages of removal reached 98.87\% for RB and $96.37 \%$ for RR, respectively. The proposed mixed adsorbent was able to remove the textile dyes, presenting adsorptive capacities of $20.77 \mathrm{mg} \cdot \mathrm{g}^{-1}$ and $19.28 \mathrm{mg} \cdot \mathrm{g}^{-1}$ for the dyes RB and RR. Regarding the adsorption kinetics, the experimental data showed that the pseudo second order model was the one that best explained the adsorptive process. For the equilibrium results, the Langmuir model and the Langmuir-Freundlich model were the ones that best fit the experimental data of RB and RR, respectively. The mixed adsorbent produced is a promising alternative for the treatment of textile effluents.
\end{abstract}

Keywords: Adsorbent, textile dye, orange peel residue.

Este estudo avalia a remoção de corantes têxteis utilizando adsorventes mistos preparados pelo crescimento de Aspergillus niger em cascas de laranja. A maior eficiência de remoção do corante azo foi obtida em $\mathrm{pH} 2$, relação sólido: líquido (1:4 g. $\left.\mathrm{mL}^{-1}\right)$ e tempo de equilíbrio de 250 minutos para cada corante. As concentrações de Remazol Black B (RB) e Remazol Red (RR) em ambos os efluentes têxteis sintéticos estavam entre 25 $\mathrm{mg} \cdot \mathrm{L}^{-1}$ e $100 \mathrm{mg} \cdot \mathrm{L}^{-1}$. O adsorvente misto foi caracterizado por difração de raios X (XRD), espectroscopia na região do infravermelho (FTIR) e microscopia eletrônica de varredura (MEV). Os resultados indicaram que houve $100 \%$ de remoção do RB e $94,85 \%$ do RR na concentração de $25 \mathrm{mg} \cdot \mathrm{L}^{-1}$. Na concentração de 100 $\mathrm{mg} \cdot \mathrm{L}^{-1}$, os percentuais de remoção atingiram $98,87 \%$ para $\mathrm{RB}$ e $96,37 \%$ para $\mathrm{RR}$, respectivamente. $\mathrm{O}$ adsorvente misto proposto foi capaz de remover os corantes têxteis, apresentando capacidades adsortivas de $20,77 \mathrm{mg} \cdot \mathrm{g}^{-1}$ e $19,28 \mathrm{mg} \cdot \mathrm{g}^{-1}$ para os corantes RB e RR. Com relação a cinética de adsorção, os dados experimentais mostraram que o modelo de pseudo-segunda ordem foi o que melhor explicou o processo adsortivo. Para os resultados de equilíbrio, o modelo de Langmuir e o modelo de Langmuir-Freundlich foram os que melhor se ajustaram aos dados experimentais do RB e RR, respectivamente. $\mathrm{O}$ adsorvente misto produzido é uma alternativa promissora para o tratamento de efluentes têxteis.

Palavras-chave: Adsorvente, corante têxtil, resíduo da casca da laranja.

\section{INTRODUCTION}

Water is essential for the survival of living beings and the maintenance of ecosystems, so that any change in its quality can cause serious problems for both socioeconomic development and the survival of organisms [1]. However, in recent years, the pollution levels of water resources (seas, rivers, lakes, etc.) have become critical, mainly due to industrial processes. The textile laundry industrial sector generates much waste in effluents, which when not treated properly, are released directly into water bodies [2]. These textile effluents from the dyeing stage have high levels of 
organic load, posing great risks to environmental quality. Among these substances, dyes, carboxylic acid salts, alkalis, surfactants, chlorinated aromatics and other chemical products are the main contaminant agents [3].

The presence of synthetic azo dyes reduces the penetration of sunlight into the water, damaging the processes of photosynthesis and the solubility of gases in the aquatic environment, as well as having low degradability due to the complexity of their chemical structures. It also causes genotoxic, mutagenic and carcinogenic effects on living organisms [4]. There is an estimative that approximately $50 \%$ of the dye applied during the dyeing stage of textiles is released into the effluent and that $36 \%$ of this belongs to the reactive dye class [5]. Among the reactive dyes which are widely used in the textile industry, can be cited the dyes Remazol Red $\left(\mathrm{C}_{25} \mathrm{H}_{15} \mathrm{~N}_{7} \mathrm{O}_{16} \mathrm{~S}_{5} \mathrm{Na}_{4} \mathrm{Cl}\right)$ and Remazol Black $\mathrm{B}\left(\mathrm{C}_{26} \mathrm{H}_{21} \mathrm{~N}_{5} \mathrm{Na}_{4} \mathrm{O}_{19} \mathrm{~S}_{6}\right)$, which have at least one chromophore azo(-N=N-) group and an electrophilic (reactive) group. They are capable of forming covalent bonds with the fibers, thus promoting the fixation of the dye to the fiber [6] .

Currently, Brazil is the fifth largest producer of textiles in the world, behind China, India, the United States and Pakistan and considered the second largest producer of "denim", the raw material for jeans production. According to the Brazilian Association of the Textile and Apparel Industry (ABIT), in 2017 there were about 29 thousand textile companies in operation, with an average textile production of 1.7 million tons and 5.9 billion pieces of clothing [7, 8]. Brazil, as well as the rest of the world, has serious problem of water contamination, since the effluent generated in many textile laundries does not meet the quality standards required by the environmental agencies; and, in many cases, there is no treatment for dye removal.

Given this, the development of alternative methods for the treatment of textile effluent is of extreme relevance and must be made economically and ecologically viable. A number of physicochemical and biological methods have been developed for the treatment of textile effluent in order to remove dyes [9]. The main methods found in the literature include the processes of adsorption [10], photochemical degradation [11], electrochemistry [12], Fenton process [13], and biodegradation [14], among others. The adsorption process is considered to be a very effective physical separation technique in the treatment of potentially polluting effluents, being efficient in the dye removal, having simple design and low cost [10]. Considering these parameters, biomasses are a widely studied alternative and also has several other advantages. They produce smaller volumes of excess sludge and has high flexibility, since it can be applied to very different types of effluents, especially if the dye-containing effluent is very toxic [14]. In view of the advantages of the two methods, new alternatives in the treatment of these effluents have been proposed, integrating biological methods and adsorption processes [15].

Considering the great importance of reuse of agro-industrial waste, a number of studies have indicated the use of biomass to adsorb pollutants with significant results, demonstrating high efficiency in the removal of pollutants even in small quantities [16]. The adsorption capacity of these nonconventional adsorbents is due to the presence of biopolymers such as polysaccharides, lignin, hemicelluloses and cellulose [17]. Among alternatives for use as natural adsorbents we can cite an orange peel [18-20]. The orange peel has high pectin content and is known to be a product that induces the formation of pectinase. Its use in the production of this enzyme by fungal microorganisms has been studied and demonstrated as adequate and viable for industrial use [21, 22].

The residue formed by this enzymatic production process, after sterilization, can be discarded as industrial waste, further increasing the problem of solids handling. Thus, studies were developed based on this substrate, composed of a fungus immobilized on agro-industrial residue, ratifying that biosorbents of microbial origin, such as fungi, can confer promising adsorbent properties in the decontamination of solutions aqueous [23]. The use of Aspergillus niger fungus has been investigated for the removal of dyes in textile effluents, especially azo dyes [24, 25] due to its ability to grow in different types of industrial bioproducts and to possess high cellular growth. However, there has been no research in literature evaluating the ability of this fungus immobilized on orange peel residue to adsorb the reactive dyes Remazol Red and Remazol Black B. In this context, the use of this residue as an adsorbent material (orange peel and fungus) is a viable and low-cost alternative for the treatment of effluents. 
Therefore, the present work aims to use an adsorbent produced by the growth of the fungus Aspergillus niger in orange peels for the removal of synthetic textile dyes from wastewaters, being evaluated the textile dyes Remazol Red and Remazol Black B.

\section{MATERIALS AND METHODS}

\subsection{Preparation of solutions and standards}

The standard curves used in this work were made from a stock solution of the dyes Remazol Black B (RB) (Figure 1A) and Remazol Red (RR) (Figure 1B) (1000 mg. $\left.\mathrm{L}^{-1}\right)$. These solutions were diluted in different concentrations $15 ; 25 ; 50 ; 100 ; 150 ; 200 ; 250$ and $300 \mathrm{mg} \cdot \mathrm{L}^{-1}$ for dye RB $\left(=0,0281 \mathrm{x}+0,0213 ; \mathrm{R}^{2}: 0,9989\right)$ and $5 ; 10 ; 15 ; 20 ; 25 ; 30$ and $40 \mathrm{mg} \cdot \mathrm{L}^{-1}$ for the $\mathrm{RR}$ dye $(\mathrm{y}=0,0191 \mathrm{x}$ - 0,0139; $\left.R^{2}: 0,9989\right)$. The absorbances of each solution were determined using a Spectrum ${ }^{\circledR}$ UV/VIS spectrophotometer, model SP-1105, whose maximum absorption wavelengths were 597 $\mathrm{nm}$ for $\mathrm{RB}$ and $514 \mathrm{~nm}$ for RR, for the tests, distilled water was used as blank.
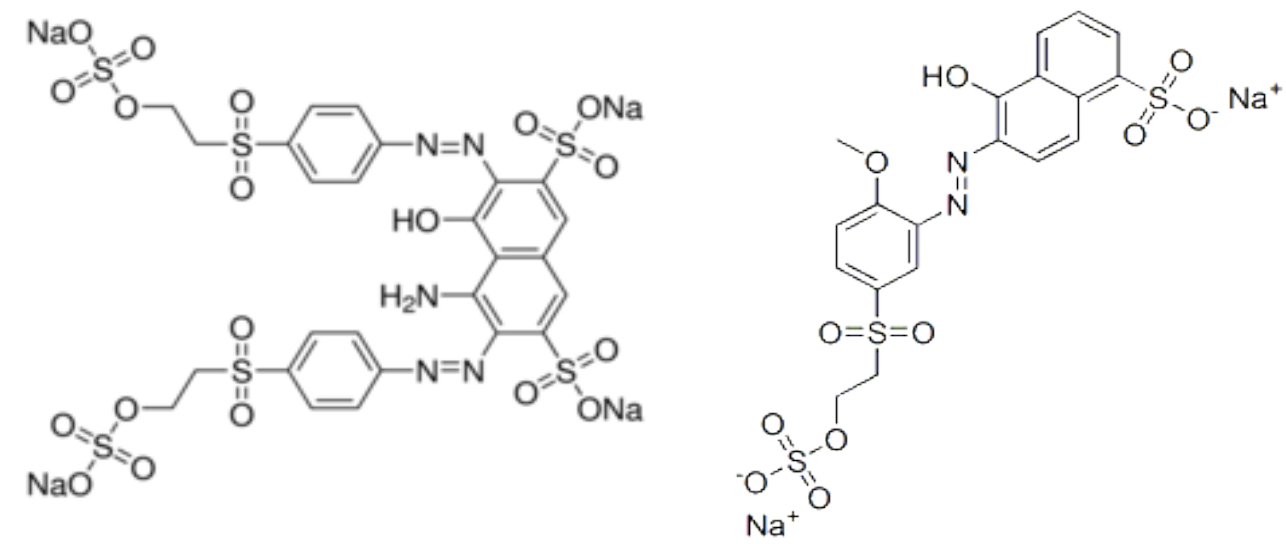

Figure 1: Structures of Remazol Black B (A) and Remazol Red (B) dyes.

\subsection{Production of mixed adsorbents}

The production of the mixed adsorbent was carried out according to the methodology proposed by Cruz et al. [26] with changes. The orange peels (Citrus sinensis L. Osbeck) (300g) were dried at $105^{\circ} \mathrm{C}$ for 24 hours, ground in a knife mill and sieved at $100 \mu \mathrm{m}$. Then they were added to weak Roux with a capacity of $1000 \mathrm{~mL}$ and autoclaved at $121^{\circ} \mathrm{C}$ for 20 minutes. The system was cooled and a suspension (in distilled water) of the fungus Aspergillus niger $(100 \mathrm{~mL})$ in a concentration of $10^{7}$ spores $\cdot \mathrm{mL}^{-1}$ was inoculated. The system was incubated at $30^{\circ} \mathrm{C}$, without shaking for 7 days. After that period, an autoclave sterilization was performed again at $121^{\circ} \mathrm{C}$ for 60 minutes, the obtained adsorbent was washed and dried in an oven for 1 day at $105^{\circ} \mathrm{C}$. The dry material was divided into three fractions (Figure 2), so that the first fraction was left untreated (MCS) (Figure 2A). The second fraction (MCA) (Figure 2C) was subjected to a treatment with hydrochloric acid $(\mathrm{HCl}) 0.1 \mathrm{~mol} \cdot \mathrm{L}^{-1}$ for $1 \mathrm{~h}$. Finally, the third fraction (MCB) (Figure $2 \mathrm{~B}$ ) was treated with sodium hydroxide $(\mathrm{NaOH}) 0.1 \mathrm{~mol} \cdot \mathrm{L}^{-1}$ also for $1 \mathrm{~h}$. After the treatment, they were washed with distilled water, until the material was neutralized, and finally dried at $105^{\circ} \mathrm{C}$ for 24 hours. 


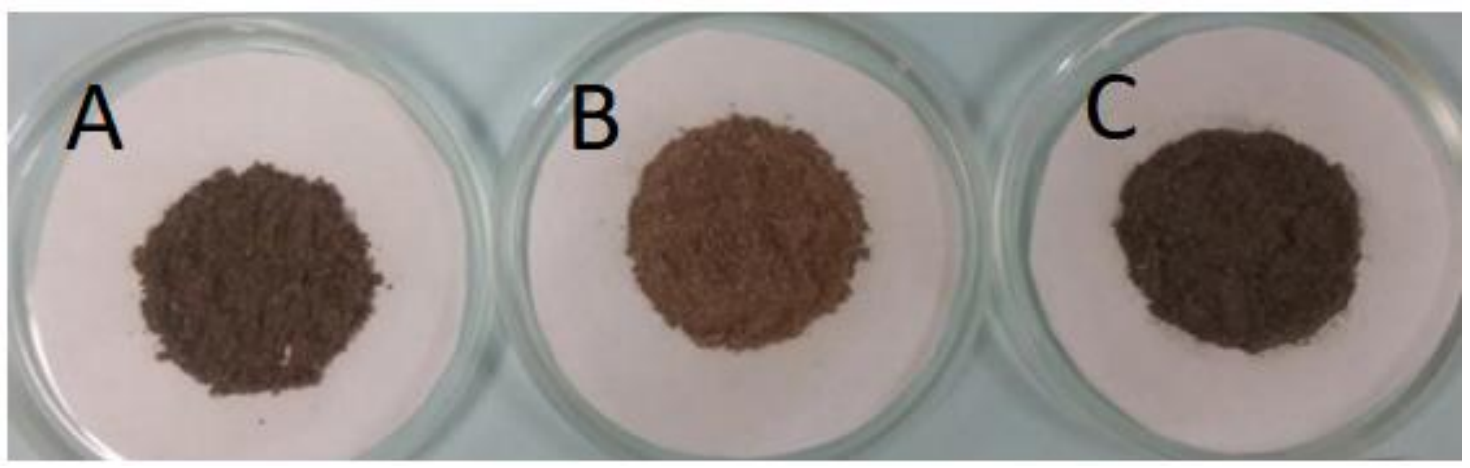

Figure 2: Produced adsorbents MCS (mixed adsorbent without treatment) (A), MCB (mixed adsorbent with basic treatment) $(B)$ e MCA (mixed adsorbent with acid treatment) $(C)$.

\subsection{Characterization of adsorbents}

The adsorbents used in this work were characterized by the following techniques: X-ray diffraction (XRD), infrared spectroscopy (FTIR), scanning electron microscopy (SEM).

The morphology of the adsorbent was analyzed using a Scanning Electron Microscope (SEM) - SHIMADZU SS-550, with a tungsten filament and coupling for EDS, voltage of $15 \mathrm{kV}$. The samples had been previously covered with a gold film, following a traditional technique, using a sputtering process with a CARON MODEL 2050-4 brand metallizer with a thin gold layer thickness of $20 \mathrm{~nm}$ and a current of 5 to $6 \mathrm{amps}$, for a time of 2 minutes to improve electrical conductivity of the surface.

Infrared spectroscopy analyses were performed in a Bruker Tensor 27 spectrometer using the Attenuated Total Reflection (ATR) technique. The absorption spectra were obtained in the infrared region (of $4000 \mathrm{~cm}^{-1}$ to $400 \mathrm{~cm}^{-1}$ ) with a resolution of $8 \mathrm{~cm}^{-1}$. The results obtained were processed using OPUS software - Version 7.2.

The X-ray diffractograms were obtained in a BRUKER x-ray diffractometer (model D8 ADVANCE) through a $\mathrm{Cu}-\mathrm{K} \alpha$ radiation source with a voltage of $30 \mathrm{kV}$ and current of $30 \mathrm{~mA}$. The data were collected in the $2 \theta$ range from $5^{\circ}$ to $80^{\circ}$ with $0.05^{\circ}$ step and 2.0 s step in time.

\subsection{Adsorption tests}

\subsection{1 $\mathrm{pH}$ influence test on the adsorptive process}

The $\mathrm{pH}$ influence study was carried out according to the methodology proposed by Cruz et al. (2016) [26] . For this, $0.5 \mathrm{~g}$ of adsorbent in dye solution (Remazol Black B or Remazol Red) was added at a concentration of $100 \mathrm{mg} \cdot \mathrm{L}^{-1}$ at different $\mathrm{pH}$ values $(2,7$ and 9). The system was maintained at $140 \mathrm{rpm}$ in a Shaker for 24 hours at $30^{\circ} \mathrm{C}$. Residual concentrations of the dyes were determined by UV/VIS spectrophotometry, using distilled water as blank. The removal percentage was calculated using Equation 1.

$$
R(\%)=\frac{100\left(C_{0}-C_{e}\right)}{C_{0}}
$$

where, $\mathrm{C}_{0}$ is the initial concentration of dye RB and RR $\left(\mathrm{mg} \cdot \mathrm{L}^{-1}\right) ; \mathrm{C}_{\mathrm{e}}$ is the concentration of the dyes at equilibrium time $\left(\mathrm{mg} \cdot \mathrm{L}^{-1}\right)$.

\subsubsection{Kinetic and equilibrium study of the adsorptive process}

The kinetic study was carried out according to Doğan et al. (2007) [27] and Tseng et al. (2014) [28] with few modifications. For this, $0.5 \mathrm{~g}$ of the adsorbent was added in $100 \mathrm{~mL}$ of the solution 
of the dyes RB or RR $\left(100 \mathrm{mg} \cdot \mathrm{L}^{-1}\right)$. The system was kept under agitation $(140 \mathrm{rpm})$ at $30^{\circ} \mathrm{C}$. Then samples at different test times $(20 ; 30 ; 40 ; 50 ; 120 ; 240 ; 300 ; 420$ and 1440 minutes) were taken and analyzed using a UV / VIS spectrophotometer, SP-1105 model. The adsorptive capacity as a function of time was determined by Equation 2 .

$$
q=\frac{V\left(C_{0}-C_{e}\right)}{m}
$$

where, $\mathrm{C}_{0}$ is the initial concentration of dye RB and RR $\left(\mathrm{mg} \cdot \mathrm{L}^{-1}\right) ; \mathrm{C}_{\mathrm{e}}$ is the concentration of the dyes at equilibrium time $\left(\mathrm{mg} \cdot \mathrm{L}^{-1}\right) ; \mathrm{V}$ is the volume $(\mathrm{mL})$ of the $\mathrm{RB}$ or $\mathrm{RR}$ dye solution and $\mathrm{m}$ is the mass of the adsorbent $(\mathrm{g})$.

The data were adjusted to the models of pseudo first order (Equation 3), pseudo second order (Equation 4) and pseudo n order (Equation 5), to study the adsorption mechanism [26-28].

$$
\begin{aligned}
& \frac{d q_{t}}{\mathrm{dt}}=k_{1}\left(q_{e}-q_{t}\right) \\
& \frac{d q_{t}}{\mathrm{dt}}=k_{2}\left(q_{e}-q_{t}\right)^{2} \\
& \frac{d q_{t}}{\mathrm{dt}}=k_{n}\left(q_{e}-q_{t}\right)^{n}
\end{aligned}
$$

where $\mathrm{q}_{\mathrm{e}}$ and $\mathrm{q}_{\mathrm{t}}$ are the amounts of dye adsorbed $\left(\mathrm{mg} \cdot \mathrm{g}^{-1}\right)$ at equilibrium and at time $\mathrm{t}$, respectively, $\mathrm{k}_{1}$ is the adsorption constant of the first order pseudo equation $\left(\mathrm{min}^{-1}\right)$ and $\mathrm{k}_{2}$ is the adsorption constant of the pseudo second-order equation $\left(\mathrm{g} \cdot \mathrm{mg}^{-1} \cdot \mathrm{min}^{-1}\right) . \mathrm{k}_{\mathrm{n}}$ is the reaction speed constant of the model pseudo $\mathrm{n}$ order and $\mathrm{n}$ is the reaction order $\left(\mathrm{kg}^{\mathrm{n}-1} \cdot \mathrm{g}^{1-\mathrm{n}} \cdot \mathrm{min}^{-1}\right)$.

For the equilibrium study, the experiments were carried out in the time established in the kinetic study, using $0.5 \mathrm{~g}$ of the adsorbent in contact with $100 \mathrm{~mL}$ of $\mathrm{RB}$ or RR solutions in concentrations of $25 ; 30 ; 35 ; 40 ; 45 ; 50 ; 55 ; 60 ; 65 ; 70 ; 75 ; 80 ; 85 ; 90 ; 95 ; 100 ; 105 ; 110 ; 115 \mathrm{mg} \cdot \mathrm{L}^{-1}$. In this study, data were adjusted to three isotherm models: Langmuir (Equation 6), Freundlich (Equation 7) and Langmuir-Freundlich (Equation 8), which are widely used to evaluate adsorption isotherms [26-28]

$$
\begin{aligned}
& q_{e}=\frac{q_{\max } \mathrm{K}_{\mathrm{L}} C_{e}}{1+\mathrm{K}_{\mathrm{L}} C_{e}} \\
& q_{e}=\mathrm{K}_{\mathrm{F}} \mathrm{C}_{e}^{1 / n F} \\
& q_{e}=\frac{q_{\max } \mathrm{K}_{\mathrm{LF}} \mathrm{C}_{e}^{1 / n L F}}{1+\mathrm{K}_{\mathrm{LF}} \mathrm{C}_{e}^{1 / n L F}}
\end{aligned}
$$

where $C_{e}$ is the equilibrium concentration of the adsorbate $\left(\mathrm{mg} \cdot \mathrm{L}^{-1}\right), \mathrm{q}_{\max }\left(\mathrm{mg} \cdot \mathrm{g}^{-1}\right)$ and $\mathrm{K}_{\mathrm{L}}\left(\mathrm{L} \mathrm{mg}^{-1}\right)$ are the Langmuir constants related to the maximum adsorption capacity and energy adsorption, respectively. The intensity of adsorption is $1 / n_{F}$ and $\mathrm{K}_{\mathrm{F}}\left(\mathrm{mg} \cdot \mathrm{g}^{-1}\right)\left(\mathrm{mg} \cdot \mathrm{L}^{-1}\right)^{-1 / n F}$ is the adsorption capacity related to the Freundlich isotherm. $\mathrm{K}_{\mathrm{LF}}\left(\mathrm{L} \cdot \mathrm{mg}^{-1}\right)^{-1 / n L F}$ is the constant of the LangmuirFreundlich isotherm and $n_{L F}$ (dimensionless) is a heterogeneity parameter.

The experimental data obtained from the equilibrium and kinetics studies were adjusted by mathematical models using a nonlinear regression method (Origin 8.0), minimizing the residual sum of squares $\left(S_{R}^{2}\right)$. The coefficient of determination $\left(R^{2}\right)$ was determined and the precision of the models being evaluated through the F-Test statistical method. 


\section{RESULTS AND DISCUSSION}

\subsection{Physicochemical characterization of adsorbents}

In Figure 3, it is possible to observe the morphology of the mixed adsorbents MCS (Figure $3 \mathrm{~A}$ and $\mathrm{B}$ ), MCA (Figure $3 \mathrm{C}$ and $\mathrm{D}$ ) and $\mathrm{MCB}$ (Figure $3 \mathrm{E}$ and $\mathrm{F}$ ) using the scanning electron microscopy (SEM) technique. It was possible to verify that all the adsorbents had an irregular surface. This fact was expected due to the fungal growth in the orange peels and the treatments (acid and basic).

The mixed adsorbent MCS (Figure $3 \mathrm{~A}$ and B) showed no pores on the surface, preserving the characteristic of orange peels. The absence of pores is confirmed by Fiorentin et al. (2010) [29] and Ströher et al. (2012) [30] featuring by SEM the orange pomace in the magnifications of 1000x and 2000x, respectively. Cruz et al. (2016) [26] evaluating the growth of Aspergillus niger in elephant grass also did not observe the formation of pores in the material. The MCA adsorbents (Figure $3 \mathrm{C}$ and D) showed greater fragmentation, followed by the MCB adsorbent (Figure $3 \mathrm{E}$ and $\mathrm{F}$ ) when compared to the MCS. The treatment stage is responsible for the structural fragmentation of the material, and the formation of pores can occur. Acid treatment promotes greater removal of polysaccharides such as pectin, which may be an indication of greater fragmentation [31-33].
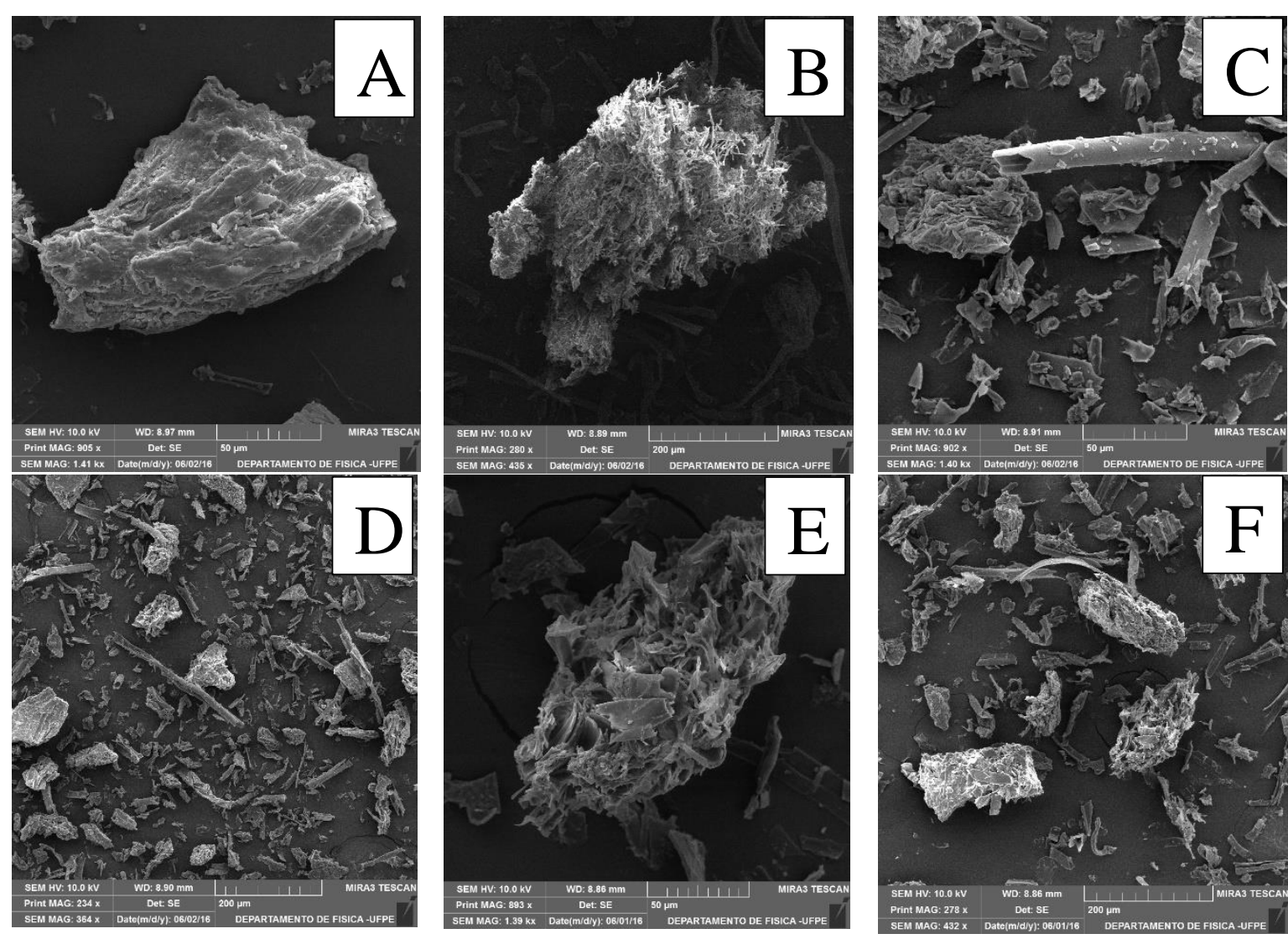

Figure 3: Electron microscopy: (A and B) MCS (mixed adsorbent without treatment); (C and D) MCA (mixed adsorbent with acid treatment); ( $E$ and $F) M C B$ (mixed adsorbent with basic treatment) amplifications of 50 and $200 \mu \mathrm{m}$ respectively.

Figure 4 shows the DRX of the adsorbents with cellulose as a standard. The peaks $(2 \theta)$ in the region from $9.0^{\circ}$ to $32^{\circ}$ were previously analyzed by Vinay et al. (2018) [34] characterizing orange peels to be used for the production of nanoparticles and by Rathinavel and Saravanakumar, (2020) [35] developing composites based on orange peel. 


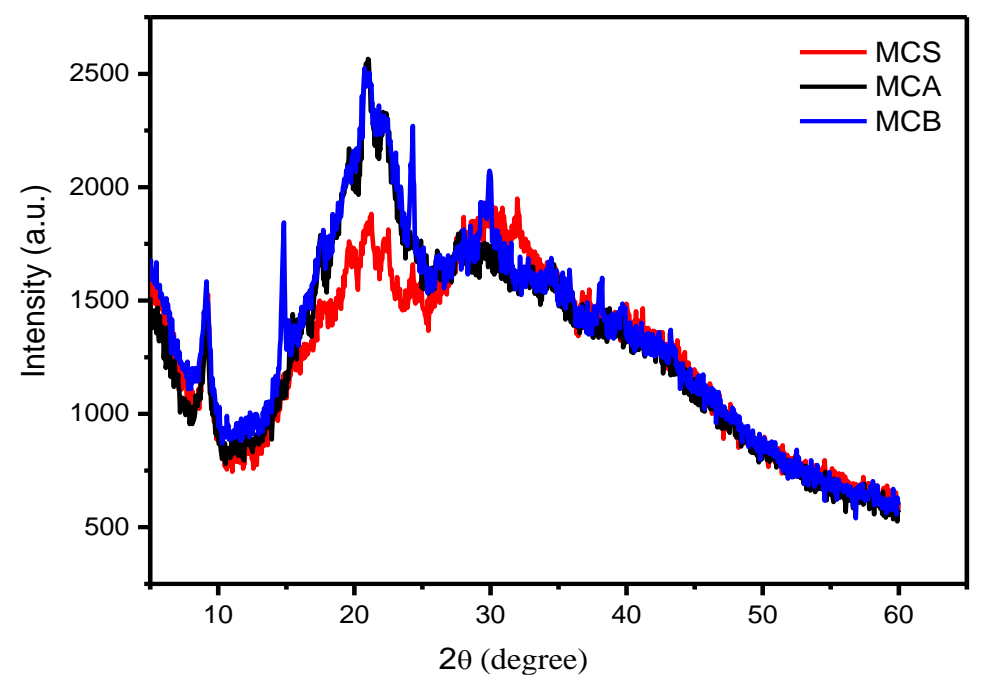

Figure 4: XRD of untreated (MCS), treated with acid (MCA) and treated with base (MCB) adsorbents.

The adsorbents produced in this study did not show well-defined peaks indicating that they are amorphous in nature, which is expected for materials with large amounts of pectin in their structure. This fact was also observed by Mafra et al. (2013) [22] using orange peels as an adsorbent for the removal of the Remazol brilliant blue dye. In Figure 5, the Fourier transform infrared (FTIR) spectra for the MCB, MCS and MCA materials are observed. In them, it is possible to identify which functional groups present in the adsorbent materials can influence the adsorption process $[36,37]$.

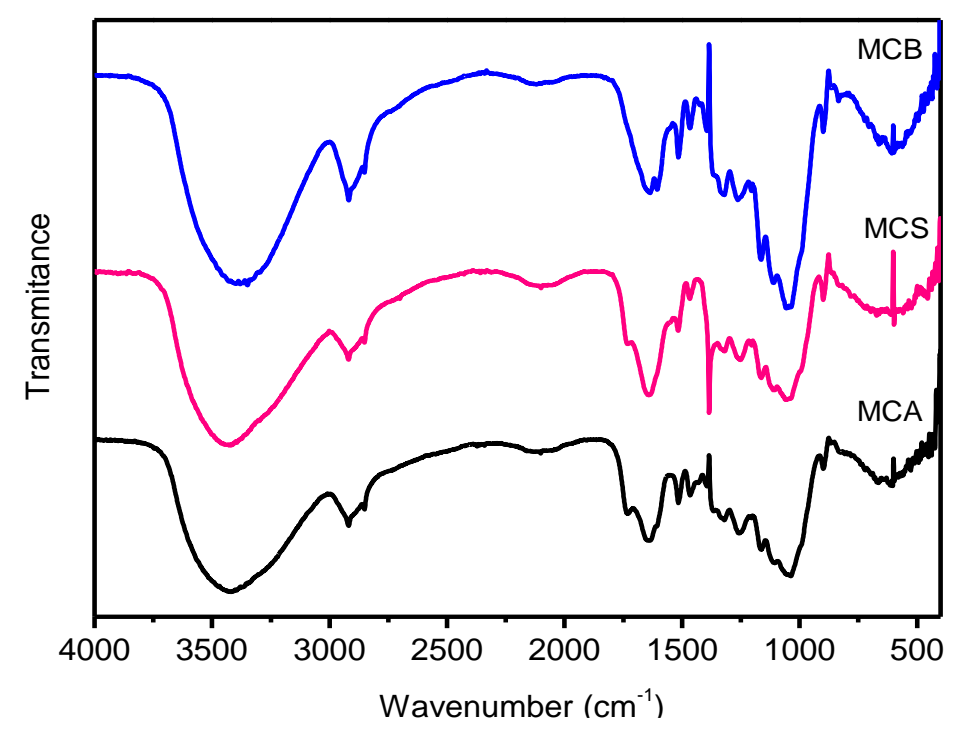

Figure 5: FTIR of untreated adsorbents (MCS), treated with acid (MCA) treated with base (MCB).

The absorption bands at $3500 \mathrm{~cm}^{-1}$ are attributed to the vibrational elongation of the $\mathrm{OH}$ bond due to the inter and intramolecular interaction of the $\mathrm{H}$ bond of polymeric compounds, macromolecular associations, such as alcohols, phenols, and carboxylic acids, as well as in pectin, cellulose and lignin [38], showing the presence of free hydroxide groups on the adsorbent surface. The bands at $2900 \mathrm{~cm}^{-1}$ and $2800 \mathrm{~cm}^{-1}$ have been attributed to $\mathrm{CH}$ interactions which are elongations of aliphatic acids [39]. The peaks in 1735 and $1629 \mathrm{~cm}^{-1}$ can be attributed to the stretching vibrations of the bonds of non-ionic carboxylic groups $\left(-\mathrm{COOH},-\mathrm{COOCH}_{3}\right)$, characteristic of carboxylic acids or their esters [39]. The bands in 1543 and $1382 \mathrm{~cm}^{-1}$ correspond to the 
asymmetrical and symmetrical vibrations of $\mathrm{C}=\mathrm{O}$ of the ionic carboxylic groups (-COO-), respectively [40]. The vibration of the aliphatic acid groups at the peak of $1193 \mathrm{~cm}^{-1}$ can be attributed to the deformation of the $\mathrm{C}=\mathrm{O}$ groups and the elongation of the formation of the $-\mathrm{OH}$ groups of carboxylic acids and phenols [41]. The bands observed in the $1095 \mathrm{~cm}^{-1}$ region may refer to the $\mathrm{C}-\mathrm{OH}$ elongation vibration of alcohols and carboxylic acids [41, 42].

The adsorbents showed similarity when it comes to functional groups located on the surface of the material. This fact may be related to the large overlap of groups, represented by broader bands presented in the FTIR spectrum. However, it is known that under acidic conditions the protonation of some functional groups occurs. This protonation favors the adsorption of anionic dyes (positively protonated functional groups and negatively charged dye). This fact was observed by Cruz et al. (2016) [26] removing the Remazol Black B dye by mixed biomass.

\subsection{Adsorption tests}

\subsection{1. pH influence test on the adsorptive process}

The chemical modifications in the adsorbent were carried out to increase, in general, the affinity and the adsorption capacity of the dyes RB and RR. The adsorption capacity of adsorbents varies depending on the characteristics of the materials, the extent of chemical changes and the concentration of adsorbate. Figure 6 shows the rate of removal of dyes in aqueous solution by untreated adsorbents (MCS), after basic treatment (MCB) and after acid treatment (MCA).
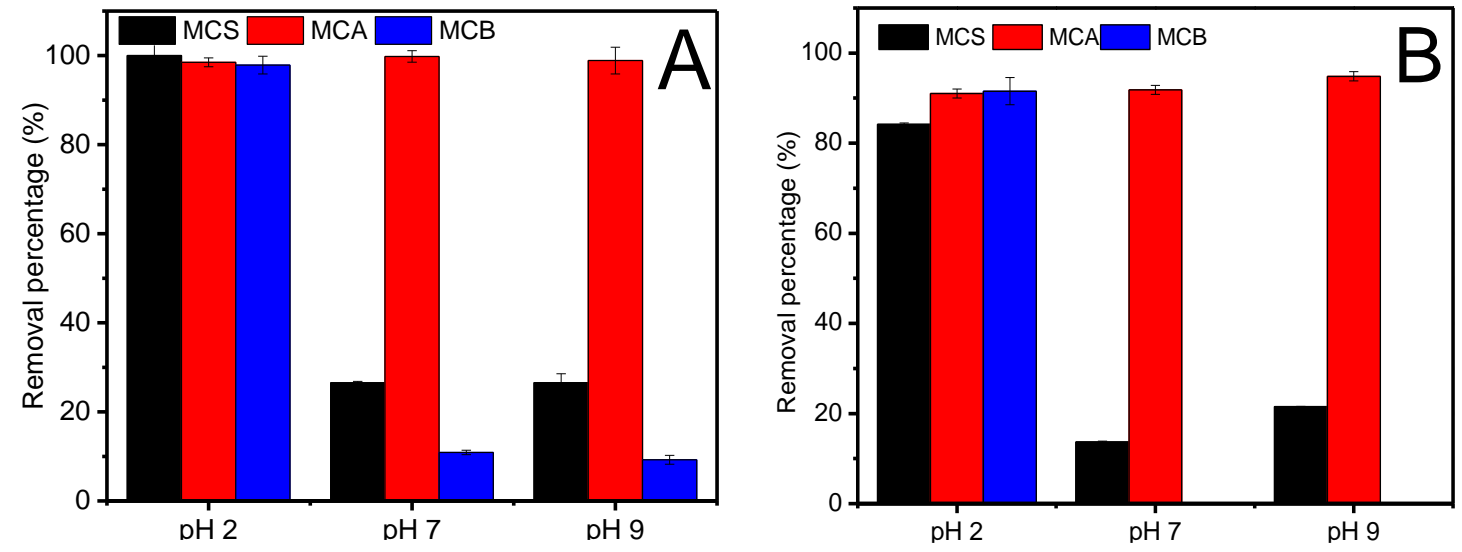

Figure 6: Percentage of removal of $R B(A)$ and $R R(B)$ dyes by adsorbents of untreated adsorbents (MCS), treated with acid $(M C A)$ and treated with base $(M C B)$ at different $p H$ values.

In Figure 6A, it is possible to observe that the adsorbents produced removed the dye Remazol Black (B) efficiently (> 98\%) at $\mathrm{pH} 2$. However, the MCA adsorbent removed the dye efficiently (> 97\%) in a wide range of $\mathrm{pH}$ (2 to 9). The Remazol Red (RR) dye removal tests (Figure 6B) showed that again the MCA adsorbent obtained a higher removal percentage (> 90\%) in a wide $\mathrm{pH}$ range, and that the MCS and MCB adsorbents only showed significant removal of the dye in acidic $\mathrm{pH}$. Thus, the adsorption process of the dyes RB and RR, using the adsorbents MCS, MCA and $\mathrm{MCB}$, was more favorable in more acidic $\mathrm{pH}$.

This behavior of high dye removal by adsorbent treated with $\mathrm{HCl}$ was also observed by Cruz et al. (2016) [26] using mixed biomass of Aspergillus niger and elephant grass and de Oliveira et al. (2018) [43], using green coconut mesocarp. This efficiency may be associated with changes in the functional groups and characteristics of the material surface, in addition to the $\mathrm{pH}$ of the solution, which directly affects the charge on the surface of the adsorbents as well as influencing the ionization of some of the solutes [44, 45]. Thus, for carrying out the kinetics and adsorption balance studies, the MCA adsorbent was chosen, because the adsorbent showed great versatility, that is, it 
was able to promote removals above $90 \%$ at different $\mathrm{pHs}$, for the dyes under study. $\mathrm{PH} 2$ was chosen to favor removal, since the dyes under study are anionic.

\subsubsection{Kinetics and equilibrium of adsorption}

The study of adsorption kinetics is essential in determining the equilibrium time, a fundamental parameter in the development of new adsorption systems, in addition to describing the adsorption capacities in different time intervals [46]. Figure 7 illustrates the adsorptive capacity of MCA against the dyes RB and RR as a function of time. These experimental data were adjusted to different kinetic models, being these: pseudo first, pseudo second and pseudo $\mathrm{n}$ order.
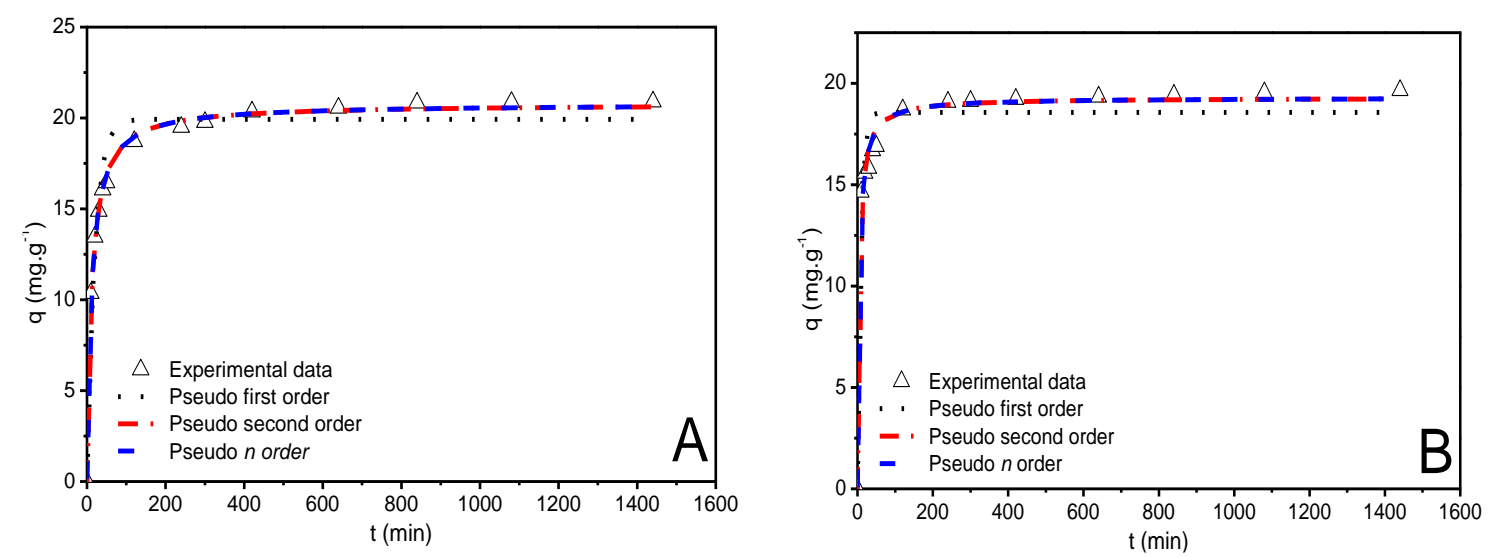

Figure 7: Kinetic profile and mathematical modeling for adsorption of $R B(A)$ and $R R(B)$ dyes by MCA (pH 2, 30C, $140 \mathrm{rpm}$; Co $\left.=100 \mathrm{mg} \cdot \mathrm{L}^{-1}\right)$.

As can be seen in Figures 7A and 7B, in the first 200 minutes, the adsorption of the dye was faster due to the large amount of empty active sites at the beginning of the adsorption. Over time, adsorption slows down due to the saturation of the adsorbent sites. The balance between the liquid and solid phases was reached in $250 \mathrm{~min}$, for both dyes. The simple and continuous shape of the curves until saturation suggests a monolayer coverage of the dye on the surfaces of the adsorbents [46].

Analyzing Figures 7A, 7B and the kinetic parameters shown in Table 1, it appears that the pseudo second order and pseudo $\mathrm{n}$ order models overlap and have $\mathrm{n}$ greater than 2 , indicating that the highest adsorption rate occurred at the beginning of the process, according to Tseng et al. (2014) [28]. Table 1 shows the kinetic parameters obtained for each model.

According to the values of $\mathrm{R}^{2}$, the pseudo second order model was the one that best fitted the experimental data for the dyes RB and RR in relation to the pseudo first order and pseudo $\mathrm{n}$ order n. However, to assess from a statistical point of view, if the model that best explains the experimental data is the pseudo second order, an F-Test was used to compare the models. The results show that for the pseudo $\mathrm{n}$ order model, $\mathrm{F}_{\mathrm{cal}}(2 / 3)<\mathrm{F}_{\mathrm{tab}}(2.46)$, considering a $95 \%$ confidence level, which indicates that there is no significant difference in relation to the second pseudo model order. Comparing the pseudo first order model, it appears that $F_{\text {cal }}(1 / 2)>F_{\text {tab }}(2.46)$, indicating that there is a significant difference for a $95 \%$ confidence level, in relation to the pseudo second order model. Therefore, because the pseudo second order and pseudo $\mathrm{n}$ order models are not statically different, the simplest chosen model that explains the adsorption process is the pseudo second order. The calculated adsorptive capacity values were very close to the experimental ones $\left(\mathrm{q}_{\text {exp }} \mathrm{RB}=20.89 \mathrm{mg} \cdot \mathrm{g}^{-1}\right.$ and $\mathrm{q}_{\mathrm{exp}} \mathrm{RR}=19.96 \mathrm{mg} \cdot \mathrm{g}^{-1}$ ) for the second order model. It assumes that the process is chemical in nature, involving the participation of valence forces or electron exchange between the adsorbate and the adsorbent [47]. 
Table 1: Parameters obtained from nonlinear regression of kinetic models for the adsorption of dyes RB and RR by mixed adsorbent (MCA).

\begin{tabular}{|c|c|c|c|}
\hline \multicolumn{4}{|c|}{ Kinetic Models } \\
\hline Models & Parameters & RB & RR \\
\hline \multirow{4}{*}{ Pseudo first order } & $q_{\text {ecalc. }}\left(\mathrm{mg} \cdot \mathrm{g}^{-1}\right)$ & $19.930 \pm 0.411$ & $18.568 \pm 0.397$ \\
\hline & $k_{l}\left(\min ^{-1}\right)$ & $0.051 \pm 0.005$ & $0.120 \pm 0.021$ \\
\hline & $S_{R}^{2}\left(\mathrm{mg}^{2} \cdot \mathrm{g}^{-2}\right)$ & 16.938 & 19.572 \\
\hline & $R^{2}$ & 0.957 & 0.937 \\
\hline \multirow{4}{*}{$\begin{array}{l}\text { Pseudo second } \\
\text { order }\end{array}$} & $q_{\text {ecalc. }}\left(\mathrm{mg} \cdot \mathrm{g}^{-1}\right)$ & $20.773 \pm 0.129$ & $19.289 \pm 0.216$ \\
\hline & $k_{2}\left(\mathrm{~g} \mathrm{mg}^{-1} \cdot \mathrm{min}^{-1}\right)$ & $0.004 \pm 1.99 .10^{-4}$ & $0.012 \pm 0.002$ \\
\hline & $S_{R}^{2}\left(\mathrm{mg}^{2} \cdot \mathrm{g}^{-2}\right)$ & 1.287 & 4.200 \\
\hline & $R^{2}$ & 0.997 & 0.987 \\
\hline \multirow{5}{*}{ Pseudo n order } & $q_{\text {ecalc. }}\left(\mathrm{mg} \cdot \mathrm{g}^{-1}\right)$ & $20.778 \pm 0.131$ & $19.290 \pm 0.226$ \\
\hline & $k_{n}\left(\mathrm{~g}^{\mathrm{n}-1} \mathrm{mg}^{1-\mathrm{n}} \cdot \mathrm{min}^{-1}\right)$ & $0.041 \pm 4.34 .10^{-4}$ & $0.012 \pm 0.002$ \\
\hline & $N$ & $2.007 \pm 0.016$ & $2.004 \pm 0.033$ \\
\hline & $S_{R}^{2}\left(\mathrm{mg}^{2} \cdot \mathrm{g}^{-2}\right)$ & 1.268 & 4.194 \\
\hline & $R^{2}$ & 0.996 & 0.985 \\
\hline \multirow{4}{*}{ F-Test } & $F_{\text {cal }}(1 / 3)$ & 13.36 & 4.67 \\
\hline & $F_{\text {cal }}(1 / 2)$ & 13.16 & 4.66 \\
\hline & $F_{\text {cal }}(2 / 3)$ & 1.01 & 1.00 \\
\hline & $F_{t a b}$ & 2.46 & 2.46 \\
\hline
\end{tabular}

The study carried out by Cunico et al. (2011) [48] using coal ash zeolite in solution with a concentration of $13 \mathrm{mg} \cdot \mathrm{L}^{-1}$ of Reactive Black 5 reactive dye, also indicated a predominance of chemosorption for the removal process, as the best fit was observed for the pseudo second order model, with an $\mathrm{R}^{2}$ greater than 0.99 . The studies showed that the results obtained indicated a good fit of the experimental data to the Langmuir model in relation to the Freundlich model. Table 2 compares the data obtained in this work with different results from the adsorptive capacity of the literature. As shown in Table 2, the differences between the equilibrium time values are related to the process conditions, type of dye and adsorbent.

Table 2. Values of the adsorption capacity in the literature.

\begin{tabular}{|c|c|c|c|c|c|}
\hline \multicolumn{6}{|c|}{ Comparative table } \\
\hline Adsorbent & Dye & $\begin{array}{l}\text { Adsorptive } \\
\text { capacity } \\
\left(\mathrm{mg} \cdot \mathrm{g}^{-1}\right)\end{array}$ & $\begin{array}{l}\text { Concentration } \\
\text { dye }\left(\mathrm{mg} \cdot \mathrm{L}^{-1}\right)\end{array}$ & $\begin{array}{c}\text { Time } \\
\text { equilibrium } \\
\text { (h) }\end{array}$ & Reference \\
\hline $\begin{array}{l}\text { Aspergillus niger }+ \\
\text { orange peel }\end{array}$ & $\begin{array}{l}\text { Remazol black B } \\
\text { Remazol red }\end{array}$ & $\begin{array}{l}20.77 \\
19.28\end{array}$ & $25-100$ & 4.2 & $\begin{array}{l}\text { This } \\
\text { work }\end{array}$ \\
\hline Aspergillus niger & Methylene Blue & 0.499 & $5-25$ & 1.67 & [49] \\
\hline Aspergillus niger & Direct Red & 0.145 & 100 & 2 & [50] \\
\hline Orange peel & $\begin{array}{l}\text { Remazol Brilliant } \\
\text { Blue }\end{array}$ & 10.7 & $30-250$ & 15 & [22] \\
\hline Orange peel & $\begin{array}{l}\text { Acid orange } 52 \\
\text { Direct red } 28\end{array}$ & $\begin{array}{l}20.5 \\
14.0\end{array}$ & $10-120$ & 24 & [51] \\
\hline Orange peel & $\begin{array}{l}\text { Direct red } 23 \\
\text { Direct red } 80\end{array}$ & $\begin{array}{l}10.7 \\
21.1\end{array}$ & $50-125$ & 0.25 & [21] \\
\hline Yeasts & Remazol Blue & 230 & $100-400$ & 4 & [52] \\
\hline Bacterial cellulose & Remazol Black B & 17.51 & $25-65$ & 1.33 & [53] \\
\hline Chitosan & Remazol red RR & 155.72 & $38-163$ & 1.08 & [54] \\
\hline
\end{tabular}


The adsorption isotherms and the nonlinear adjustments of the Langmuir, Freundlich and Langmuir-Freundlich models are shown in Figures 8 for both dyes. In Table 3, the parameters of the adsorption equilibrium models calculated for RB and RR can be seen.
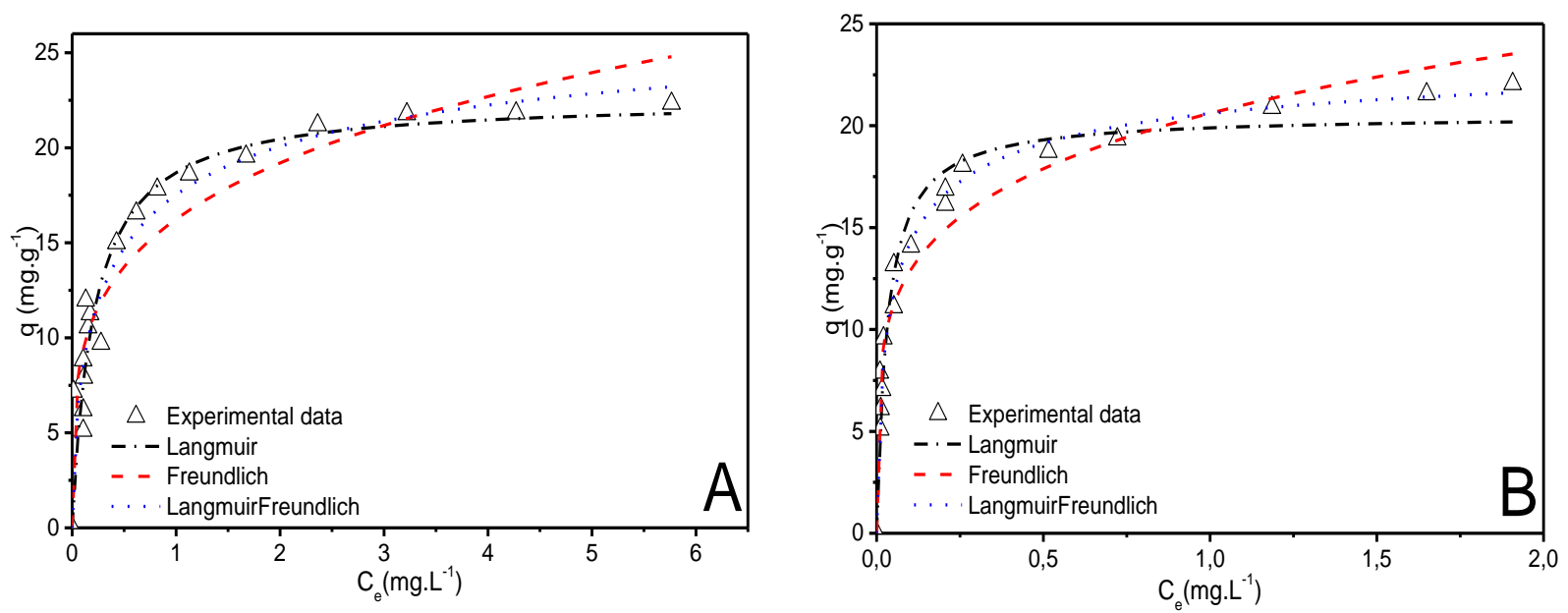

Figure 8: Experimental data and calculated data obtained from the adjustments to the models for

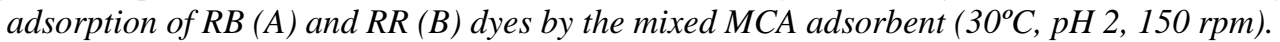

According to the values of $\mathrm{R}^{2}$ for the two dyes, the Langmuir-Freundlich model was the one that obtained the best fit in relation to the Langmuir and Freundlich models, also suggested by obtaining the lowest values for $S_{R}{ }^{2}$. However, through the results of the statistical analysis of the F-Test, it is noted that for the RB dye, at a $95 \%$ confidence level, there was no significant difference between the use of this model when compared to Langmuir's $\left(\mathrm{F}_{\mathrm{cal}}(1-3)<\mathrm{F}_{\mathrm{tab}}\right)$ or Freundlich's $\left(\mathrm{F}_{\mathrm{cal}}(2-3)<\right.$

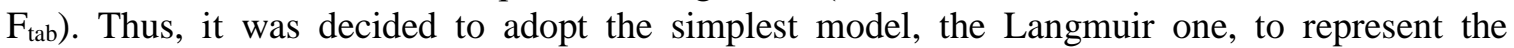
experimental data.

Table 3: Parameters obtained of adjustment of equilibrium data of the adsorption of the dyes RB and RR by the mixed adsorbent MCA to the models.

\begin{tabular}{cccc}
\hline \multicolumn{4}{c}{ Isotherm parameters } \\
\hline Models & Parameters & RB & RR \\
\hline & $q_{\max }\left(\mathrm{mg} \cdot \mathrm{g}^{-1}\right)$ & $22.586 \pm 1.021$ & $20.521 \pm 0.583$ \\
Langmuir $^{(1)}$ & $K_{L}\left(\mathrm{~L} \cdot \mathrm{mg}^{-1}\right)$ & $4.803 \pm 0803$ & $31.763 \pm 4.219$ \\
& $S_{R}{ }^{2}$ & 68.833 & 27.210 \\
& $R^{2}$ & 0.908 & 0.958 \\
\hline & $K_{F}$ & $16.240 \pm 0.527$ & $20.610 \pm 0.637$ \\
Freundlich $^{(2)}$ & $\left(\mathrm{mg} \cdot \mathrm{g}^{-1}\right)\left(\mathrm{mg} \cdot \mathrm{L}^{-1}\right)^{-1 / n F}$ & $4.140 \pm 0.401$ & $4.892 \pm 0.414$ \\
& $n_{F}$ & 71.545 & 39.432 \\
& $S_{R}{ }^{2}$ & 0.905 & 0.939 \\
& $R^{2}$ & $28.442 \pm 5.617$ & $24.058 \pm 1.441$ \\
Langmuir- $^{(3)}$ & $q_{\text {max }}\left(\mathrm{mg} \cdot \mathrm{g}^{-1}\right)$ & $1.605 \pm 0.948$ & $5.950 \pm 2.125$ \\
& $K_{F L}\left(\mathrm{~L} \cdot \mathrm{mg}^{-1}\right)^{-1 / n L F}$ & $1.723 \pm 0.473$ & $1.627 \pm 0.197$ \\
& $n_{L F}$ & 54.577 & 11.424 \\
& $S_{R}{ }^{2}$ & 0.923 & 0.981 \\
\hline \multirow{2}{*}{ F-Test } & $R^{2}$ & 1.04 & 1.45 \\
& $F_{\text {cal }}(1-2)$ & 1.26 & 2.38 \\
& $F_{\text {cal }}(1-3)$ & 1.31 & 3.45 \\
& $F_{\text {cal }}(3-2)$ & 2.16 & 2.23 \\
\hline
\end{tabular}


In the case of the RR dye, it is noted that the Langmuir-Freundlich model really showed a significant difference at a $95 \%$ confidence level, obtaining higher $\mathrm{F}_{\text {cal }}$ values than the $\mathrm{F}_{\text {tab }}$ when compared to the other models used. Thus, this model was selected in the experimental data description of adsorption equilibrium of RR dye by the biosorbent.

Mafra et al. (2013) [22] studied orange peels in the adsorption of Remazol Brilliant Blue. Its experimental parameters followed two types of isotherms: Langmuir and Freundlich, composing a mixed system of mono and multilayer adsorption. A comparison of the results obtained in this work with different outcome of the adsorptive capacity reported in the literature is presented in Table 2. Arami et al. (2005) [21] used orange peels to remove the dyes Direct Red 23 (DR23) and Direct Red 80 (DR80) and a removal capacity equivalent to 92 and $91 \%$ was observed at $\mathrm{pH} 2$ for DR23 and DR80, respectively. The studies also showed that the results obtained indicated a positive adjustment of the experimental data to the Langmuir model in relation to the Freundlich model.

Comparing the results of the present work with those found in the literature, it is observed that the best result was found by Aksu and Dönmez (2003) [52], who used Saccharomyces cerevisiae as an adsorbent for the treatment of solutions containing the dyes Remazol Red and Remazol Black B in concentrations that ranged from 10 to $400 \mathrm{mg} \cdot \mathrm{L}^{-1}$. The other studies obtained results of adsorptive capacity varying from $13.82 \mathrm{mg} \cdot \mathrm{g}^{-1}$ to $21.05 \mathrm{mg} \cdot \mathrm{g}^{-1}$ for several dyes. The results obtained with agro-industrial waste were like those found in this study.

\section{CONCLUSION}

Based on the results obtained, under local conditions, it can be observed that the studied adsorbent collected from the orange peel inoculated with Aspergillus niger showed satisfactory adsorption capacity to remove the Remazol Black B and Remazol Red dyes in synthetic textile effluents. This adsorbent is a suitable option for this purpose, since, in the proposed form, it is already an industrial process residue. Therefore, its use as an adsorbent brings double benefit when using one residue to treat another.

\section{ACKNOWLEDGMENT}

The authors are grateful to the Brazilian Coordination for the Improvement of Higher Education Personnel (CAPES) has granted masters scholarship to K. C. de Souza. The Federal University of Pernambuco and the Rural Federal University of Pernambuco for analyzes of the material.

\section{REFERENCES}

1. Rodda JC. Eau sous pression. Hydrol Sci J. 2001;46(6):841-54, doi: 10.1080/02626660109492880

2. Kant R. Textile dyeing industry an environmental hazard. Nat Sci. 2012;04(01):22-6, doi: 10.4236/ns.2012.41004

3. Singh RL, Singh PK, Singh RP. Enzymatic decolorization and degradation of azo dyes - A review. Int Biodeterior Biodegrad. 2015;104:21-31. Available from: 10.1016/j.ibiod.2015.04.027

4. Brüschweiler BJ, Küng S, Bürgi D, Muralt L, Nyfeler E. Identification of non-regulated aromatic amines of toxicological concern which can be cleaved from azo dyes used in clothing textiles. Regul Toxicol Pharmacol. 2014;69(2):263-72, doi: 10.1016/j.yrtph.2014.04.011

5. Gulzar T, Huma T, Jalal F, Iqbal S, Abrar S, Kiran S, et al. Bioremediation of synthetic and industrial effluents by aspergillus Niger isolated from contaminated soil following a sequential strategy. Molecules. 2017;22(12), doi: 10.3390/molecules22122244

6. Yildiz E, Bozok N. Synthesis of compounds containing fluorine, vinylsulfone groups and transition metal complexes and their applications to textiles. E-Journal Chem. 2008;5(Suppl. 1):997-1007, doi: $10.1155 / 2008 / 348037$

7. Pinheiro E, de Francisco AC, Piekarski CM, de Souza JT. How to identify opportunities for improvement in the use of reverse logistics in clothing industries? A case study in a Brazilian cluster. J Clean Prod. 2019;210:612-9, doi: 10.1016/j.jclepro.2018.11.024 
8. Leal Filho W, Ellams D, Han S, Tyler D, Boiten VJ, Paco A, et al. A review of the socio-economic advantages of textile recycling. J Clean Prod. 2019;218:10-20, doi: 10.1016/j.jclepro.2019.01.210

9. Turan-Ertas T. Biological and physical-chemical treatment of textile dyeing wastewater for color and COD removal. Ozone Sci Eng. 2001;23(3):199-206, doi: 10.1080/01919510108962003

10. El-Geundi MS. Colour removal from textile effluents by adsorption techniques. Water Res. 1991;25(3):271-3, doi: 10.1016/0043-1354(91)90006-C

11. Donkadokula NY, Kola AK, Naz I, Saroj D. A review on advanced physico-chemical and biological textile dye wastewater treatment techniques. Rev Environ Sci Biotechnol. 2020;19(3):543-60, doi: $10.1007 / \mathrm{s} 11157-020-09543-\mathrm{z}$

12. Kariyajjanavar P. Degradation of textile wastewater by electrochemical method. J Waste Water Treat Anal. 2011;02(01):1-7, doi: 10.4172/2157-7587.1000110

13. D. Patil A, Raut PDPD. Treatment of textile wastewater by Fenton's process as a Advanced Oxidation Process. IOSR J Environ Sci Toxicol Food Technol. 2014;8(10):29-32, doi: 10.9790/2402-081032932

14. Kanagaraj J, Senthilvelan T, Panda RC. Biodegradation of azo dyes in industrial effluent: An eco-friendly way toward green technology. Clean Technol Environ Policy. 2015;17(2):331-41, doi: 10.1007/s10098014-0783-y

15. Bhatia D, Sharma NR, Singh J, Kanwar RS. Biological methods for textile dye removal from wastewater: A review. Crit Rev Environ Sci Technol. 2017;47(19):1836-76, doi: 10.1080/10643389.2017.1393263

16. Mirbagheri SA, Charkhestani A. Pilot-scale treatment of textile wastewater by combined biologicaladsorption process. Desalin Water Treat. 2016;57(20):9082-92, doi: 10.1080/19443994.2015.1029525

17. Saha P. Assessment on the removal of methylene blue dye using tamarind fruit shell as biosorbent. Water Air Soil Pollut. 2010;213(1-4):287-99, doi: 10.1007/s11270-010-0384-2

18. Kamble B, Bhusari P, Shah V, Mane V, Suryawanshi M. Industrial waste water treatment using natural adsorbents. IJAERD. 2017;876-81, doi: 10.21090/IJAERD.12397

19. Hameed BH, Krishni RR, Sata SA. A novel agricultural waste adsorbent for the removal of cationic dye from aqueous solutions. J Hazard Mater. 2009;162(1):305-11, doi: 10.1016/j.jhazmat.2008.05.036

20. Abdurrahman F Bin, Akter M, Abedin MZ. Dyes removal from textile wastewater using orange peels. Int J Sci Technol Res. 2013;2(9):47-50.

21. Arami M, Limaee NY, Mahmoodi NM, Tabrizi NS. Removal of dyes from colored textile wastewater by orange peel adsorbent: Equilibrium and kinetic studies. J Colloid Interface Sci. 2005;288(2):371-6, doi: $10.1016 /$ j.jcis. 2005.03 .020

22. Mafra MR, Igarashi-Mafra L, Zuim DR, Vasques ÉC, Ferreira MA. Adsorption of remazol brilliant blue on an orange peel adsorbent. Brazilian J Chem Eng. 2013;30(3):657-65, doi: 10.1590/S010466322013000300022

23. Gupta VK, Suhas. Application of low-cost adsorbents for dye removal - A review. J Environ Manage. 2009;90(8):2313-42, doi: 10.1016/j.jenvman.2008.11.017

24. Agarry S, Ayobami O. Evaluation of microbial systems for biotreatment of textile waste effluents in Nigeria: Biodecolourization and biodegradation of textile dye. J Appl Sci Environ Manag. 2011;15(1):7986. doi: $10.4314 /$ jasem.v15i1.65680

25. Assadi MM, Jahangiri MR. Textile wastewater treatment by Aspergillus niger. Desalination. 2001;141(1):1-6, doi: 10.1016/S0011-9164(01)00383-6

26. Cruz IJ, Marques LM, de Souza KC, de Lima VF, Marques OM, do Nascimento Junior AJ. Remoção do corante remazol black b pelo uso da biomassa mista de Aspergillus niger e capim elefante (Pennisetum purpureum schum). Engevista. 2016;18(2):265, doi: 10.22409/engevista.v18i2.727

27. Doğan M, Özdemir Y, Alkan M. Adsorption kinetics and mechanism of cationic methyl violet and methylene blue dyes onto sepiolite. Dye Pigment. 2007;75(3):701-13, doi: 10.1016/j.dyepig.2006.07.023

28. Tseng RL, Wu PH, Wu FC, Juang RS. A convenient method to determine kinetic parameters of adsorption processes by nonlinear regression of pseudo-nth-order equation. Chem Eng J. 2014;237:153-61, doi: 10.1016/j.cej.2013.10.013

29. Fiorentin LD, Menon BT, de Barros STD, Pereira NC, Lima OCM, Modenes AN. Isotermas de sorção do resíduo agroindustrial bagaço de laranja. Rev Bras Eng Agrícola e Ambient. 2010;14(6):653-9, doi: 10.1590/s1415-43662010000600012

30. Ströher AP, de Menezes ML, Fiorentin LD, Pereira NC. Utilização do bagaço de laranja no tratamento de efluente proveniente da lavagem de jeans. E-Xacta. 2012;5(1):27-37, doi: 10.18674/exacta.v5i1.766

31. Munhoz CL, Sanjinez-Argandoña EJ, Soares-Júnior MS. Extração de pectina de goiaba desidratada. Cienc e Tecnol Aliment. 2010;30(1), doi: 10.1590/s0101-20612010005000013

32. Jiang LQ, Fang Z, Li XK, Luo J, Fan SP. Combination of dilute acid and ionic liquid pretreatments of sugarcane bagasse for glucose by enzymatic hydrolysis. Process Biochem. 2013;48(12):1942-6, doi: 10.1016/j.procbio.2013.09.012 
33. Moretti MMS, Bocchini-Martins DA, Nunes CCC, Villena MA, Perrone OM, da Silva R, et al. Pretreatment of sugarcane bagasse with microwaves irradiation and its effects on the structure and on $\begin{array}{llll}\text { enzymatic } & \text { hydrolysis. } & \text { Appl }\end{array}$ http://dx.doi.org/10.1016/j.apenergy.2014.02.020

34. Vinay CH, Goudanavar P, Acharya A. Development and characterization of pomegranate and orange fruit peel extract based silver nanoparticles. J Manmohan Meml Inst Heal Sci. 2018;4(1):72-85, doi: 10.3126/jmmihs.v4i1.21146

35. Rathinavel S, Saravanakumar SS. Development and analysis of poly vinyl alcohol/orange peel powder biocomposite films. J Nat Fibers. 2020;1-10, doi: 10.1080/15440478.2019.1711285

36. Sakkayawong N, Thiravetyan P, Nakbanpote W. Adsorption mechanism of synthetic reactive dye wastewater by chitosan. J Colloid Interface Sci. 2005;286(1):36-42, doi: 10.1016/j.jcis.2005.01.020

37. Hevira L, Rahmi A, Zein R, Zilfa Z, Rahmayeni R. The fast and of low-cost-adsorbent to the removal of cationic and anionic dye using chicken eggshell with its membrane. Mediterr J Chem. 2020;10(3):294301, doi: 10.13171/mjc02003261271lh

38. Gnanasambandam, R., Proctor A. Determination of pectin degree of esterification by diffuse reflectance. Food Chem. 2000;68:327-32.

39. Li X, Tang Y, Xuan Z, Liu Y, Luo F. Study on the preparation of orange peel cellulose adsorbents and biosorption of $\mathrm{Cd} 2+$ from aqueous solution. Sep Purif Technol. 2007;55(1):69-75, doi: 10.1016/j.seppur.2006.10.025

40. Farinella NV., Matos GD, Arruda MAZ. Grape bagasse as a potential biosorbent of metals in effluent treatments. Bioresour Technol. 2007;98(10):1940-6, doi: 10.1016/j.biortech.2006.07.043

41. Guibaud G, Tixier N, Bouju A, Baudu M. Relation between extracellular polymers' composition and its ability to complex $\mathrm{Cd}, \mathrm{Cu}$ and $\mathrm{Pb}$. Chemosphere. 2003;52(10):1701-10, doi: 10.1007/s11270-010-03842

42. Souza JVT, Massocatto CL, Diniz KM, Tarley CRT, Caetano J, Dragunski DC. Adsorção de cromo (III) por resíduos de laranja in natura e quimicamente modificados. Semin Ciências Exatas e Tecnológicas. 2012;33(1):3-16, doi: 10.5433/1679-0375.2012v33n1p3

43. de Oliveira FM, Coelho LM, de Melo EI. Avaliação de processo adsortivo utilizando mesocarpo de coco verde para remoção do corante azul de metileno. Rev Mater. 2018;23(4):e-12223, doi: 10.1590/s1517707620180004.055

44. Cardoso NF, Lima EC, Pinto IS, Amavisca CV., Royer B, Pinto RB, et al. Application of cupuassu shell as biosorbent for the removal of textile dyes from aqueous solution. J Environ Manage. 2011;92(4):123747, doi: 10.1016/j.jenvman.2010.12.010

45. Chang J, Ma J, Ma Q, Zhang D, Qiao N, Hu M, et al. Adsorption of methylene blue onto Fe3O4/activated montmorillonite nanocomposite. Appl Clay Sci. 2016;119:132-40, doi: 10.1016/j.clay.2015.06.038

46. Qiu H, Lv L, Pan BC, Zhang QJ, Zhang WM, Zhang QX. Critical review in adsorption kinetic models. J Zhejiang Univ Sci A. 2009;10(5):716-24, doi: 10.1631/jzus.A082052447.

47. Ho YS, McKay G. Sorption of dye from aqueous solution by peat. Chem Eng J. 1998;70(2):115-24.

48. Cunico P, Fungaro DA, Denise A, Magdalena PC. Adsorção do reativo preto 5 de solução aquosa por zeólita de cinzas de carvão: estudos cinéticos e de equilíbrio. Periódico Tchê Quimica. 2011;6(12):1-8.

49. Sivasamy A, Sundarabal N. Biosorption of an azo dye by Aspergillus niger and Trichoderma sp. fungal biomasses. Curr Microbiol. 2011;62(2):351-7, doi: 10.1007/s00284-010-9713-3

50. Mahmoud MS, Mostafa MK, Mohamed SA, Sobhy NA, Nasr M. Bioremediation of red azo dye from aqueous solutions by Aspergillus niger strain isolated from textile wastewater. J Environ Chem Eng. 2017;5(1):547-54, doi: 10.1016/j.jece.2016.12.030

51. Annadurai G. Adsorption of basic dye on strongly chelating polymer: Batch kinetics studies. Iran Polym J (English). 2002;11(4):237-44.

52. Aksu Z, Dönmez G. A comparative study on the biosorption characteristics of some yeasts for Remazol Blue reactive dye. Chemosphere. 2003;50(8):1075-83, doi: 10.1016/S0045-6535(02)00623-9

53. Leal ANR, Lima ACA, Azevedo MGFA, Santos DKDN, Zaidan LEMC, Lima VF, Cruz Filho IJ. Removal of Remazol Black B dye using bacterial cellulose as an adsorbent. Sci Plena. 2021 Mar;17(3):034201, doi: 10.14808/sci.plena.2021.034201

54. Kabir MP, Islam MM, Masum SM, Hossain MM. Adsorção de vermelho de remazol RR em quitosana a partir de solução aquosa. Bangladesh J Sci Ind Res. 2014;49(2):111-8, doi: 10.3329/bjsir.v49i2.22005 